\title{
Gyermekkori csonttörések vizsgálata ultrahanggal
}

\author{
DR. VARGA MARCELL'1, DR. TÓTH LUCA르, DR. GARANCSY GLÓRIA², \\ DR. RIBES KITTI², DR. PINTÉR SÁNDOR²
}

\section{ÖSSZEFOGLALÁS}

Bár az ultrahanggal végzett törésdiagnosztika lehetősége évtizedek óta ismert, a módszer mégsem terjedt el rutinszerűen. A magas frekvenciájú transzducerek, illetve nagy felbontású készülékek elterjedésével, továbbá a klinikusok által végzett „point of care” vizsgálatok egyre népszerúbbé válásával a szonográfiás törésdiagnosztika ismét az érdeklődés középpontjába került. Gyermekkorban szerepe felértékelődik, mert csökkentheti a felesleges röntgenvizsgálatok számát, illetve gyorsíthatja az akut ellátást. A kedvező tapasztalatok és az egyre növekvő számú tanulmány ellenére ugyanakkor a mai napig nem állnak rendelkezésünkre magas szintű evidenciák. Cikkünkben összefoglaljuk az akut gyermektraumatológiai ellátás során alkalmazható ultrahangos törésdiagnosztikai lehetőségeket, ezek előnyeit és potenciális klinikai alkalmazásukat. A szerzők megjegyzik, hogy a bemutatott módszerek kiegészítő lehetőségek, céljuk nem a röntgenvizsgálatok teljes helyettesítése, hanem a diagnosztikus hatékonyság növelése, biztonságosabbá tétele, valamint a felesleges sugárexpozíció csökkentése.

\section{Kulcsszavak: $\quad$ Diagnosztika; Gyermekkor; Radiográfia; Törések; Ultrahang;}

M. Varga, L. Tóth, G. Garancsy, K. Ribes, S. Pintér: Ultrasound diagnostics of fractures in children

Although ultrasound diagnostics of bone fractures has been known for decades, the method has not spread widely. With the development of high-frequency and high-resolution devices, as well as the growing popularity of point-of-care examinations by clinicians, sonographic fracture diagnostics have once again become the focus of interest. It is particularly important in childhood, by reducing the number of unnecessary $\mathrm{x}$-ray examinations and speeding up acute care. Despite the positive experiences and the increasing number of studies, we still have no high-level evidence to date. In our article, we summarize the ultrasonic diagnostic options for paediatric bone fractures, their benefits and their potential clinical application. The authors note that the methods presented are complementary and not intended to replace $\mathrm{X}$-ray examinations, but to increase diagnostic efficacy, make it safer and reduce unnecessary radiation exposure.

Keywords: $\quad$ Child; Fractures, bone - Diagnostic imaging; Point-of-Care Systems; Radiography; Ultrasonography - Methods; 


\section{BEVEZETÉS}

A magas frekvenciájú transzducerekkel végzett mozgásszervi ultrahang diagnosztika az elmúlt években jelentős fejlődésen esett át, és egyre általánosabbá vált használata az akut ellátás során is $(8,9)$. A nemzetközi irodalom az ultrahang ilyen irányú alkalmazását sokszor a „point of care” jelzővel illeti (22). A fenti kifejezést magyarra fordítani nehéz, de általánosságban olyan, klinikus által végzett ultrahangos gyorsdiagnosztikát jelent, ami célzott klinikai kérdésre keresi a választ. Intézetünkben 2011 óta alkalmazunk klinikus által végzett akut mozgásszervi ultrahang diagnosztikát a gyermektraumatológiai ellátás során.

A csonttörések szonográfiás diagnosztikai lehetőségéről Leitgeb számolt be először 1986-ban (31). Magyarországon Farbaky Zsófia és munkatársai írtak először a csonttörések szonográfiás vizsgálatáról (20). Bár azóta számos tanulmány született, amely az egyes testtájékok ultrahangos törésdiagnosztikájának effektivitását igazolta, a módszer nem terjedt el rutinszerűen $(7,10,12,25,41,45)$. Ennek több oka is lehet. Egyrészt az ultrahang diagnosztika nem alkalmazható valamennyi töréstípusnál egységesen, másrészt speciális jártasságot, szervezést igényel használata az akut ellátás során (7, 10, 12, 25). A magas frekvenciájú, nagy felbontású készülékek klinikai gyakorlatban való elterjedésének köszönhetően ugyanakkor a közelmúltban ismét az érdeklődés középpontjába került (11).

A legtöbb tanulmányt angolszász rendszerű sürgősségi osztályok végezték, a szonográfiás törésdiagnosztikát itt általában az ellátást gyorsító triage, illetve további képalkotás igénybevételének eldöntéséhez való szűrés céljából alkalmazzák (11). További kutatások igazolták az ultrahang törések észlelésében való diagnosztikus előnyeit harctéri övezetekben, illetve forrásaiban korlátozott egészségügyi ellátó helyeken $(7,12,11)$. Az ultrahang ugyanakkor egyéb kiegészítő képalkotást szükségtelenné tevő definitív diagnosztikaként is használható, főleg bizonyos gyermekkori töréstípusok esetén. Ilyen irányú, hagyományosan inkább ortopéd-traumatológus által végzett diagnosztikáról a német típusú ellátási rendszerekben számoltak be leginkább (2, 16-18, 24, 27).

Gyermekkorban a mozgásszervi ultrahang szerepe felértékelődik, mivel ionizáló sugárzással nem jár, relatíve olcsó, non-invazív diagnosztikai módszerről van szó. Cikkünkben áttekintést nyújtunk a gyermekkori ultrahangos törésdiagnosztika módszeréről, illetve bemutatjuk a lehetséges alkalmazási területeket.

\section{FIZIKAI ALAPOK}

A csontot érő ultrahangnyaláb lényegében teljes egészében reflektálódik. A csöves csontok corticalisát, arra merőlegesen és hossztengelyére párhuzamosan tartott lineáris transzducerről kibocsátott ultrahangnyalábokkal, egyenes vonalként lehet leképezni. A modern készülékekkel akár már néhány tizedmilliméter nagyságú corticalis megszakadás is vizualizálható (12). A gyermekkorra jellemző, csontcorticalis deformációval járó sérülések (torus törések, angulatióval járó zöldgally törések) típusos mintázatot adnak (7). A törési résben képződő fokozatosan csontosodó, kezdetben lágy callus jelenléte az ultrahangnyalábok részleges visszaverése miatt jóval hamarabb látható. Ezt a törésgyógyulás korai detektálásában, illetve callodiastasis ellenőrzésében (végtaghosszabbítás) lehet kihasználni (1. ábra) $(26,50)$. A nagyrészt porcos elemeket tartalmazó, még minimális ossificatiót mutató, hagyományos röntgen számára sokszor „láthatatlan" ízületi alkotóelemek (apophysis magok, avulsiós fragmentumok) is sokszor vizualizálhatóak ultrahanggal (46). 


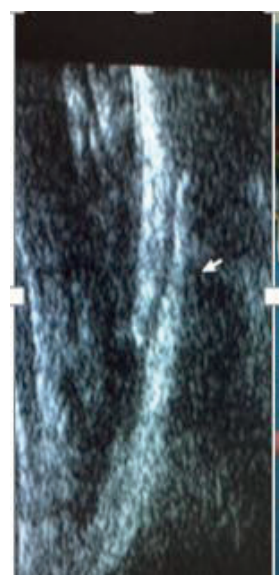

a

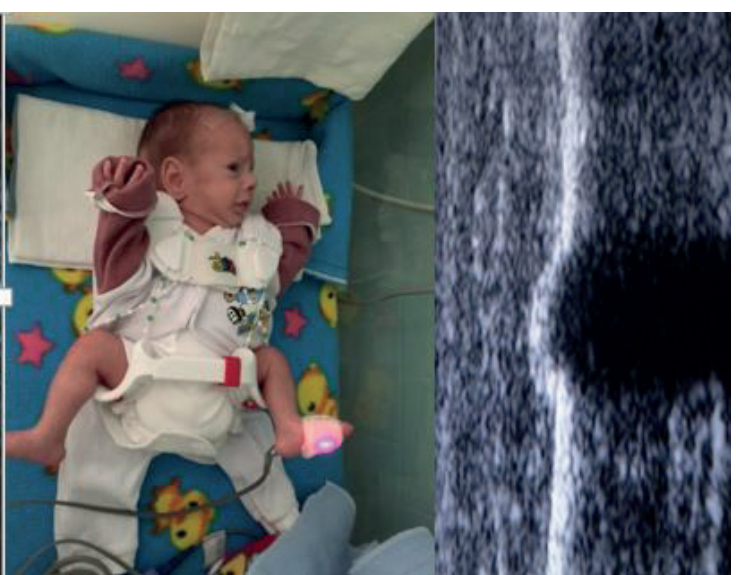

b

C

\section{1. ábra}

a) Koraszülött gyermek femur diaphysis törése

b) A femurtörés ebben az életkorban 1-2 hét alatt konszolidálódik, a kezelés konzervativ c) Két héttel később készült ultrahangfelvételen a csont corticalison kialakuló dombszerü előboltosulás szolíd callus jelenlétére utal, a felhelyezett brace biztonsággal eltávolítható, röntgen kontroll nem szükséges

\section{SZEMÉLYI ÉS TÁRGYI FELTÉTELEK}

A célzott törésdiagnosztikára irányuló ultrahangvizsgálathoz a szonográfiás alapképzettség már elegendő lehet, ugyanakkor fontos szempont a gyermektraumatológiai ellátásban való jártasság is. Bár a csontok corticalisa egyszerűbb, alacsonyabb frekvenciájú (10-12 MHz) lienáris transzducerekkel is leképezhető, a környező lágyrészek vizsgálata, illetve az egyes rétegek határozott elkülönítése csak magasabb frekvenciájú (>10-18 MHz), nagyfelbontású készülékkel valósítható meg. Az ellenoldal vizsgálatát összehasonlítás céljából általában érdemes elvégezni. A modern készülékekben a betegek rögzített ultrahangos képei tárolhatók, visszakereshetők.

\section{ALKALMAZÁSI LEHETŐSÉGEK TESTTÁJÉKOK SZERINT}

\section{Koponyatörések}

Gyermekkorban a fejsérülés az egyik vezető halálok. A gyermekkori koponya trauma optimális diagnosztikus algoritmusa, illetve a potenciálisan súlyos következményekkel járó esetek kiszúrése a mai napig szakmai vita tárgya. A hagyományos kétirányú koponya röntgenfelvételek alacsony szenzitivitásuk, míg a CT felvételek magas sugárterhelésük miatt nem alkalmazhatóak minden esetben és rutinszerűen. Boltozati, körülírt duzzanat, illetve fluktuáló terime esetén az ultrahang értékes kiegészítő képalkotó eljárás a koponyacsont-folytonosság megszakadásának igazolásában. Hátránya, hogy csak akkor informatív, ha a törés az erőbehatás területén alakul ki. A vizsgálatokat legalább két, egymásra merőleges síkban el kell végezni. Bár fejsérülés esetén az ultrahang csak kiegészítő diagnosztikus metódus, prioritását a hagyományos röntgenfelvételekkel szemben számos tanulmány igazolta $(13,36,39)$. (2-3. ábra). 


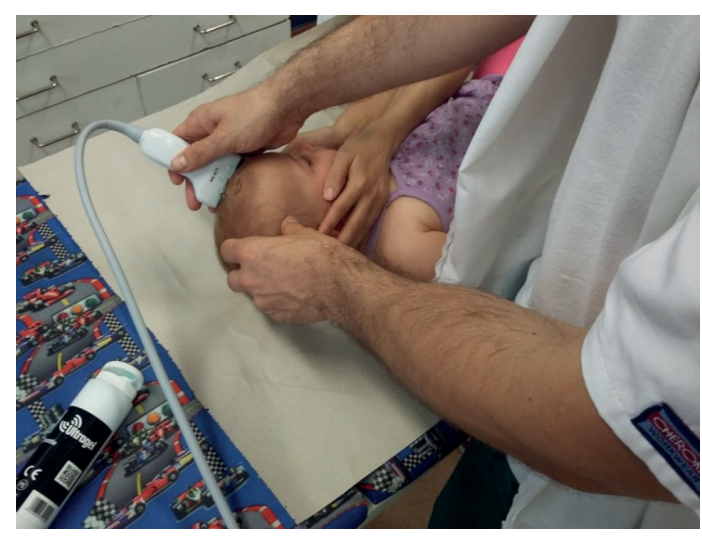

2. ábra Koponya vizsgálata ultrahanggal

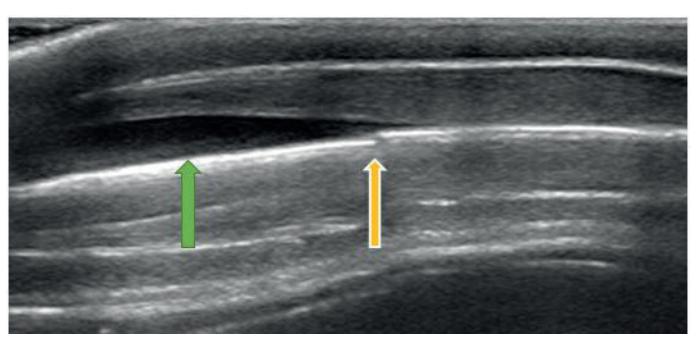

3. ábra Koponya boltozati csont törése. Az ultrahang felvételen jól látszik a csont corticalis megszakadása (sárga nyíl), illetve a subgalealis haematoma (zöld nyíl)

megtartottságával járó angulált, vagy torus törései, valamint a clavicula hasonló sérülései a röntgenfelvételekkel lényegében egyező effektivitással igazolhatóak. Nagy dislocatióval járó, esetlegesen mútéti ellátást igénylő sérülések során az ultrahang igazolja a súlyosság fokát, de a pontos konfiguráció megítéléséhez a röntgen elengedhetetlen $(1,15)(4-5$. ábra).

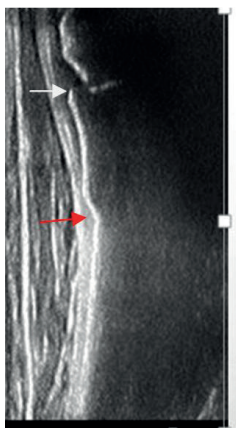

\section{5. ábra}

Proximalis humerus metaphysis torus jellegü törésének ultrahang-és röntgenképe.

A fehér nyil az epiphysis fúgára, a piros nyíl a torus törésre mutat 


\section{Könyöktáji törések}

A gyermekkori könyöktáji törések nagyon gyakoriak tízéves kor alatt. A diagnosztikát nehezíti, hogy a könyökízület több csontosodási magból fejlődik, amelyek megjelenése változó. A könyökízület porcos részeit érintő törések röntgenfelvételen sokszor egyáltalán nem láthatóak, pedig akár mútéti indikációval is járhatnak. Ultrahang segítségével vizsgálható a dorsalis szonográfiás zsírpárna jel (az intraarticularis és extrasynovialis zsírpárna kóros elhelyezkedésének, a zsírpárna dislocatiójának) jelenléte, illetve hiánya, amely a radiológiai zsírpárna jelnél sokkal szenzitívebb. A vizsgálat során a fossa olecrani fölé helyezett transzducerrel igazolható, hogy a zsírpárna dislocatiójakor, annak előboltosulása a humerus corticalisának szintjét meghaladja-e. Negatív esetben a klinikai konzekvenciával járó intraarticularis törés jelenléte lényegében kizárható. További standard síkok vizsgálatával a diagnosztika még hatékonyabbá tehető $(1,17$, 18) (6-7. ábra).

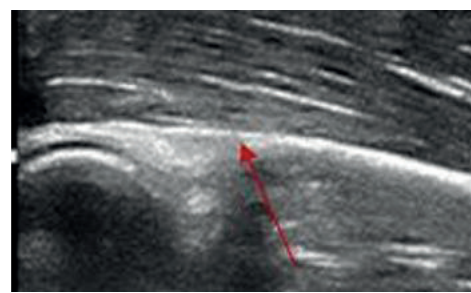

a

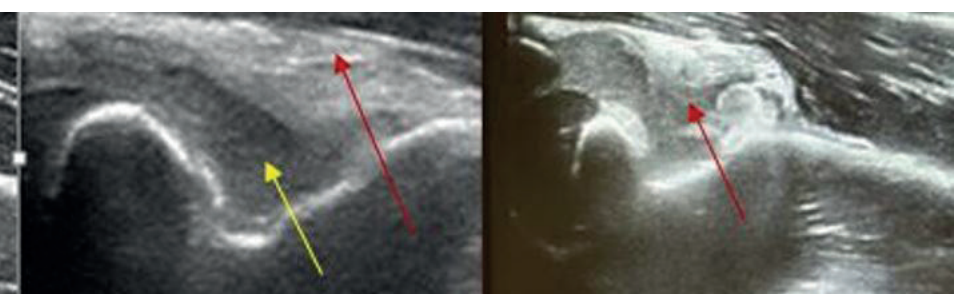

b

C

\section{6. ábra}

a) Szonográfiás zsírpárna jelek a fossa olecraniban (longitudinális metszet). A szabályos elhelyezkedésü dorsalis echodús zsírpárna (normális zsírpárna jel) lényegében az intraarticularis törés jelenlétét kizárja (piros nyíl)

b) Elevált zsírpárna jel. A normál echodús zsírpárna (piros nyíl) kiemelkedik a kóros ízületi folyadékgyülem (sárga nyill) miatt. Ízületi vérzésre, illetve okkult könyöktáji törésre utal.

c) Lipohaemarthros. A fossa olecraniban inhomogén bevérzésre jellemző, belső echokat tartalmazó, kóros folyadékgyülem megjelenése könyöktáji törés jele (piros nyíl)

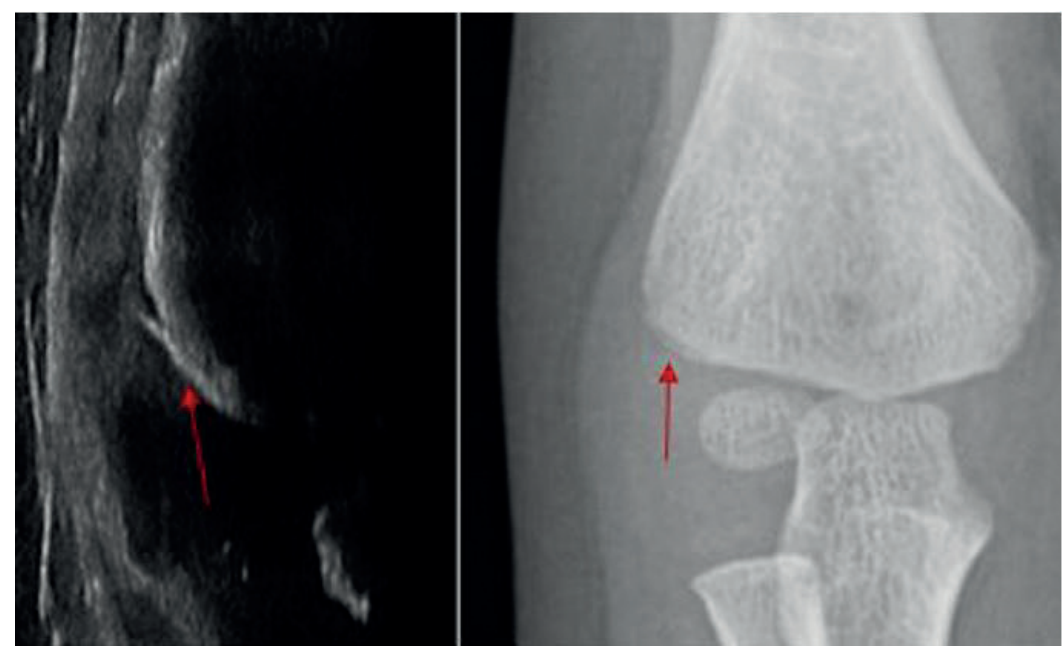

\section{7. ábra}

Elmozdulás nélküli radialis condylus törés ultrahang- és röntgenképe 


\section{Distalis alkartörések}

A gyermekkori csuklótáji törések a gyermekkor leggyakoribb sérülései. A szonográfiás törésdiagnosztika legáltalánosabban tanulmányozott régiója. Több tanulmány is igazolta, hogy a szonográfia ugyanolyan hatékony, mint a röntgen a gyermekkori distalis radius és ulnatörések esetén $(1,44,48,51)$. A vizsgálat hat standard sík felvételével néhány perc alatt elvégezhető (48). Remodellációs kapacitást meghaladó angulációval járó törések, vagy dislocált epiphyseolysisek esetén a repozíció eredményessége röntgen helyett ultrahangvizsgálattal is ellenőrizhető (51) (8-9. ábra).

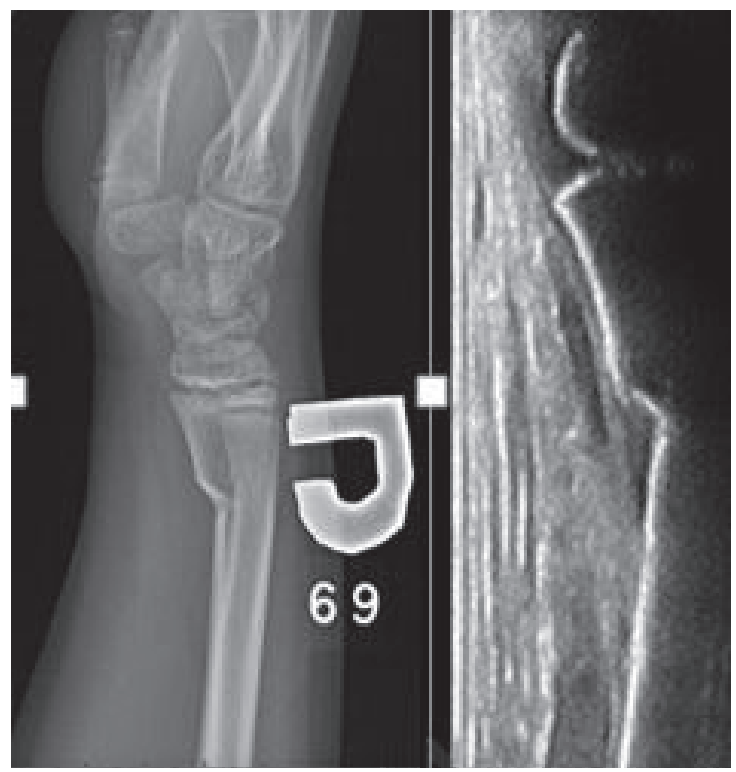

8. ábra

Jelzett ventralis billenéssel járó distalis radius metaphysis törés röntgen- és ultrahangképe
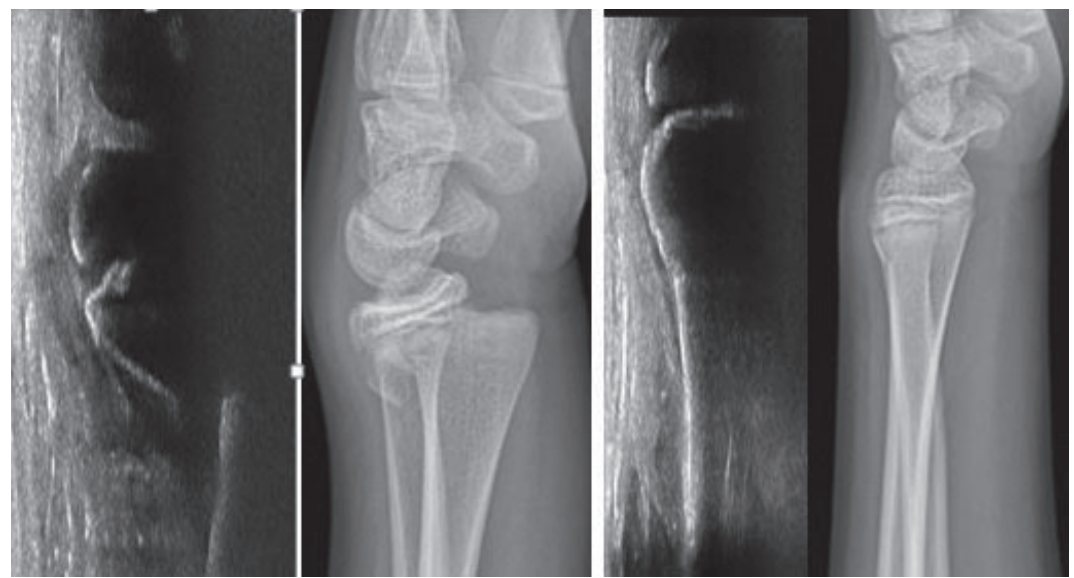

\section{9. ábra}

Salter-Harris II-es epiphyseolysis ultrahang-és röntgenképe, valamint a repozíció után készült ultrahang-és röntgenfelvételek 


\section{Kézközépcsont és ujjtörések}

A hosszú ujjak PIP és DIP ízületi avulsiói, epiphyseolysisei, illetve a metacarpusok diaphysisét, végpercét érintő törések egyaránt jól vizualizálhatóak gyermekkorban. Hasonlóan a csuklótájékhoz az V-ös metacarpus fej billenéssel járó törései reponálhatóak is szonográfiás ellenőrzés mellett. A mútéti indikációt képező tengelyeltérések, diastasisok ugyancsak észlelhetőek, de ezekben az esetekben pontos ábrázolás csak röntgen igénybevétele mellett lehetséges $(4,47)$.

\section{Csípőtáji sérülések}

Számos gyermekkori, a csípőt érintő patológiás folyamattal először baleseti ambulancián jelentkeznek elsődleges ellátásra, mert sokszor valamilyen sérüléssel hozzák összefüggésbe. A csípő elülső ferde síkból végzett ultrahangos gyorsdiagnosztikájának a hagyományos röntgendiagnosztika mellett számos előnye lehet. Bár a csípőízületi folyadékszaporulat ritkán utal traumára, jelenléte, rutin szürése, gyermekkori csípő- és térdtáji fájdalmak esetén nagyon sok segítséget nyújthat egyes kórképek megerősítésében, illetve kizárásában.

A három leggyakoribb gyermekkori csípőtáji folyamat - transitorius coxitis, Legg-Calvé-Perthes kór, illetve serdülókori combfej epiphyseolysis - fennállása jóval hamarabb megállapító. Serdülőkori combfej epiphyseolysis kezdeti stádiumában az ultrahangon látható lehet az ízületi folyadékszaporulat, valamint az epiphysis fúga kiszélesedése, így szenzitivebb lehet a röntgennél, amely ilyenkor gyakran még semmilyen elváltozást nem mutat $(14,35)$.

A részben elcsontosodott medencetáji apophysis magok serdülőkori avulsiós törései többnyire sportolás, illetve hirtelen nagy energiájú izomtevékenység során alakulnak ki, hagyományos röntgenfelvételekkel gyakran nagyon nehéz a megítélésük és differenciáldiagnosztikai problémát jelenthetnek. Célzott ultrahangvizsgálat megerősítheti a klinikai gyanút (10. ábra).

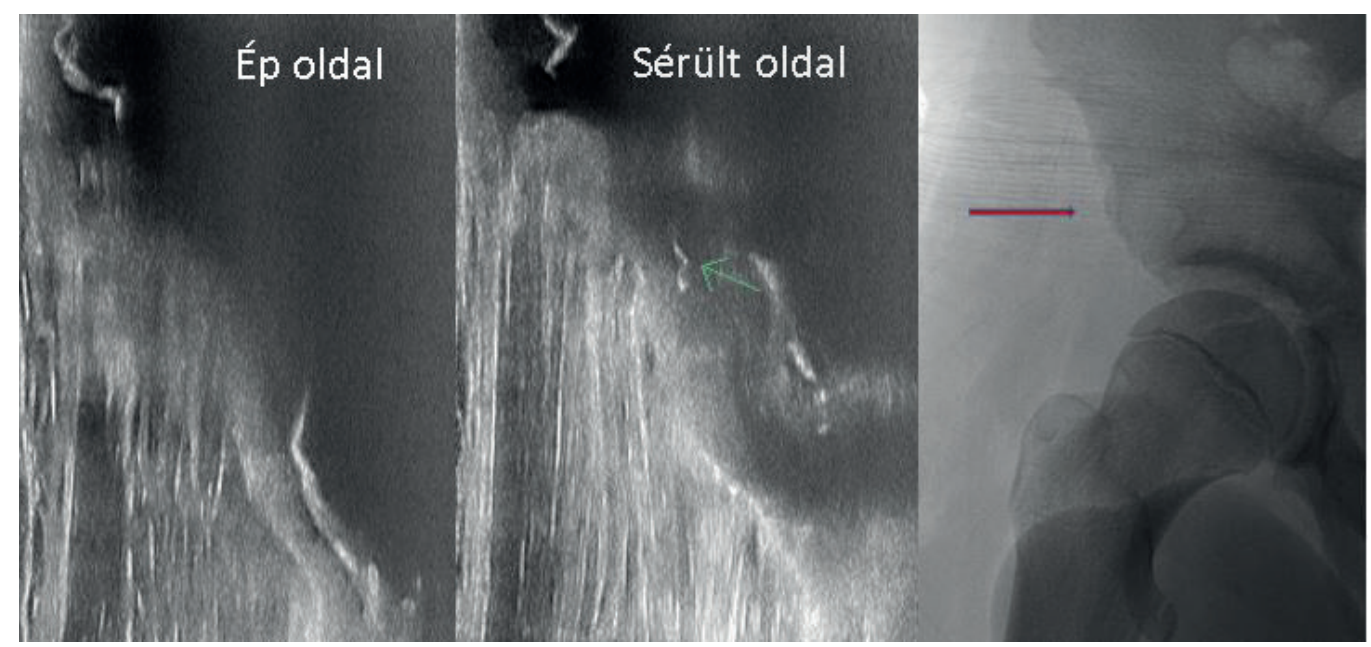

10. ábra

Spina iliaca anterior inferior avulsiós törése 15 éves sportoló gyermeknél. Míg a röntgenfelvételen csak sejthetö a törés (piros nyil), az összehasonlitó ultrahangképen az ép oldallal összehasonlítva egyértelmüen látható az avulsiós fragmentum (zöld nyil). 


\section{Térdtáji sérülések}

A gyermekkorban jelentkező térdtáji panaszok hátterében számos patológiás folyamat húzódhat. A diagnosztikát nehezíti, hogy a gyermekek elsődleges vizsgálata sokszor egyáltalán nem mozgásszervi specialista által történik. Hasonlóan a csípőízülethez, a térdízületi folyadékszaporulat - amely szonográfiával nagyon szenzitíven, egyszerűen igazolható - mindig patológiás folyamatra (törés, szalagsérülés, gyulladás) utal. Röntgenfelvétellel nem igazolható okkult törések, porcfelszín sérülés, retinaculum avulsiós törések, amelyek terápiás konzekvenciát jelenthetnek is észlelhetőek „point of care” ultrahanggal. A fenti esetekben a legfőbb elöny, hogy a gyors, sugárterheléssel nem járó és olcsó vizsgálat felhívhatja a figyelmet a további relatív sürgős diagnosztika (MRI) és terápia (artroszkópia) szükségességére $(3,6,28,29)$ (11-12. ábra).

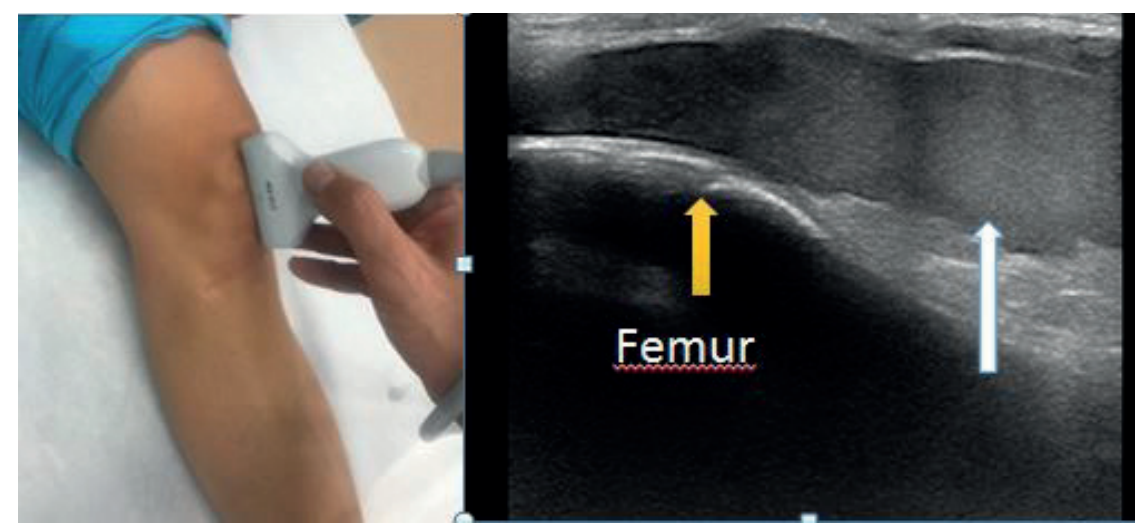

11. ábra

Haemarthros genus vizsgálata és ultrahangképe. A longitudinális síkban végzett vizsgálattal látható a femur corticalisa, illetve a növekedési zóna (sárga nyil), valamint a recessus suprapatellarisban elhelyezkedő jelentős mennyiségü, sürü, csaknem homogén ízületi folyadékgyülem (fehér nyil)

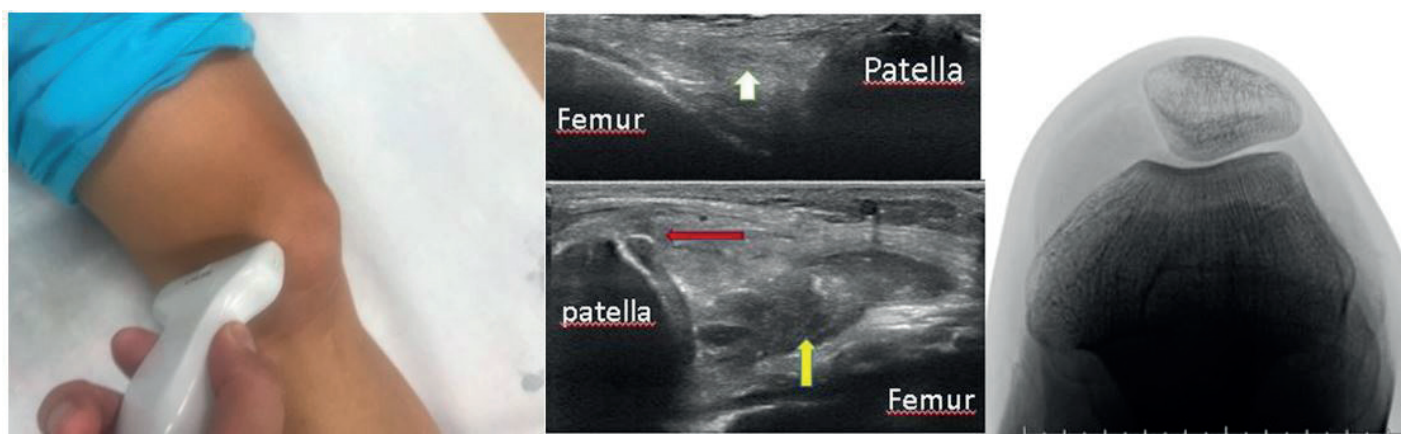

12. ábra

Patellaficam utáni állapot, medialis retinaculum vizsgálata. Az ép oldallal összehasonlítva látható, hogy a medialis retinaculum szabályos szerkezete (fehér nyíl) a sérült oldalon a patellán történő tapadásnál, a kis avulsiós fragmentum (piros nyil). A retinaculum alatt folyadékgyülem látható (sárga nyíl) 


\section{Lábszártörések}

Gyermekkori lábszársérülések esetén az ultrahang effektíven alkalmazható a nagy dislocatióval járó törések primer rögzítése, vagy helyretétele során a megfelelő tengelyállás ellenőrzésére, illetve konzervatív kezelés során a redislocatio kizárására.

A még csak részleges csontosodást mutató tuberositas tibiae avulsiós töréseinél is fontos szerepe lehet az ultrahangnak a sérülés fokának megítélésében.

Speciális eset a kisgyermekkori kis traumára kialakuló izolált tibia infractiós sérülés (Toddler's fracture), amely a primeren sokszor negatív röntgenfelvételek miatt sokszor kifejezett differenciáldiagnosztikai problémát jelent. A csont corticalis megszakadása ezekben az esetekben általában szonográfiával igazolható $(32,37,38)$

\section{Bokatáji törések}

A gyermekkori bokatáji sérülések rutinszerúen alkalmazott diagnosztikus vizsgálata a háromirányú röntgenfelvétel. Ismert tény

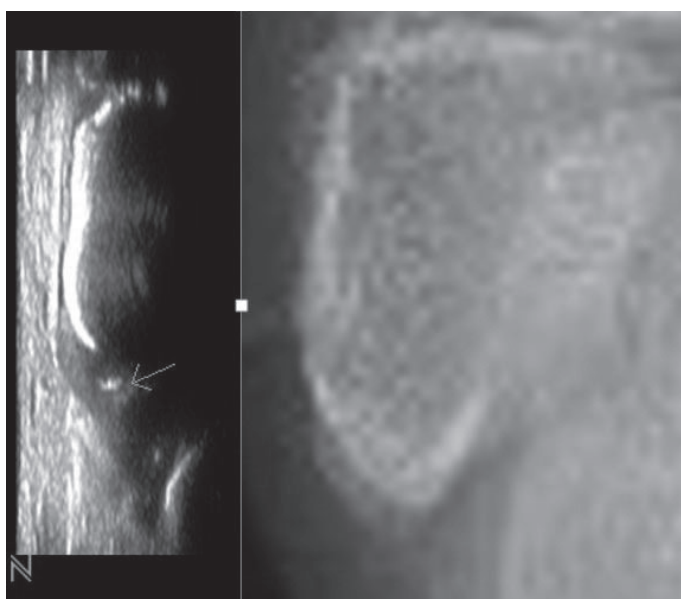

13. ábra

Külboka avulsiós törés ultrahangképe. A röntgenfelvételen csak sejthetö, hogy a külboka csúcsából egy kis fragmentum kiszakadt (nyil) ugyanakkor, hogy gyermekkorban csak az esetek kevesebb, mint 5\%-ában igazolódik csontos eltérés. Emiatt egyes ajánlások csak a járásképtelenséggel és nagy duzzanattal járó esetekben javasolják egyáltalán a röntgen képalkotás igénybevételét. Néhány szerző a röntgenhez hasonló diagnosztikus értékúnek találta az ultrahangot a külbokatörések kizárásában. A gyermekkora jellemző fibula distalis vég héjszerú szalagos avulsiói sokszor csak ultrahanggal vizualizálhatóak. A fentiek alapján járásképességüket megtartott, bokasérült gyermekek esetén sokkal inkább az ultrahang lenne optimális az elsődlegesen választandó képalkotó eljárásnak $(19,33)(13 . a ́ b r a)$.

\section{Lábcsont-törések}

A lábujjak, metatarsusok sérülései a kéz ujjaihoz hasonló effektivitással vizsgálhatóak. $\mathrm{Az}$ ultrahang kifejezett segítséget nyújthat az V. metatarsus bázistörések megítélésében, valamint a törés, illetve korcsoportra jellemző apophysis magok elkülönítésében $(30,40)$ (14. ábra), illetve az avulsiós sérülések diagnosztizálásában.

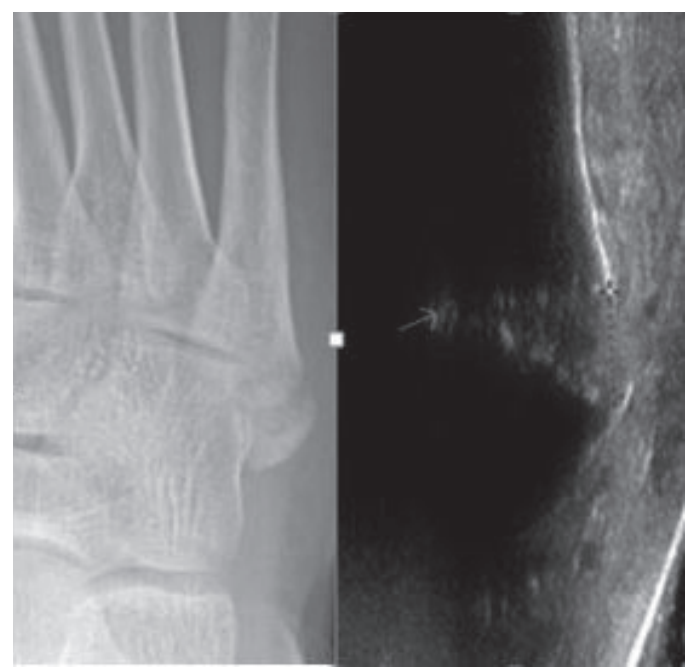

14. ábra

Metatarsus bázistörés röntgen- és ultrahangképe. A törésben kialakult diastasis megítélése hagyományos röntgenfelvételen sokszor nehéz. A lateralis síkból felhelyezett transzdúcer segítségével az elmozdulás mértéke ultrahangvizsgálattal pontosan meghatározható (nyíl) 


\section{SPECIÁLIS ESETEK}

\section{Gyermekbántalmazás}

Gyermekbántalmazás gyanúja esetén az ultrahang jelentős segítséget nyújthat egyéb régebbi, addig nem felismerésre került törések detektálásában. Szonográfiával a csöves csontok további potenciális sérüléseinek szűrése effektíven végezhető el, ennek különösen kisdedek, kisgyermekek subperiostealis töréseinek esetén van jelentősége. Ezekben az esetekben a callusképződés gyorsan bekövetkezik, így a törés klinikailag már kevésbé észlelhető, ha a gyermeket később viszik orvoshoz
- ugyanakkor az ossificálódó csonthártya alatti haematoma jellegzetes ultrahang képe sokáig vizualizálható $(34,49)$.

\section{Stressztörések}

Az ultrahangnak nagy szerepe lehet különböző stressztörések korai identifikálásában. Stressztörésre utalhat a megvastagodott periosteum, a corticalis vonalának disruptiója, illetve Doppler aktivitás fokozódása, a hypervascularisatio megjelenése az érintett csontszegmens környezetében. Ezek a jelek akár hetekkel korábban is kimutathatóak, mint a röntgenfelvételen legkorábban látható morfológiai elváltozások $(21,23)(15$. ábra).

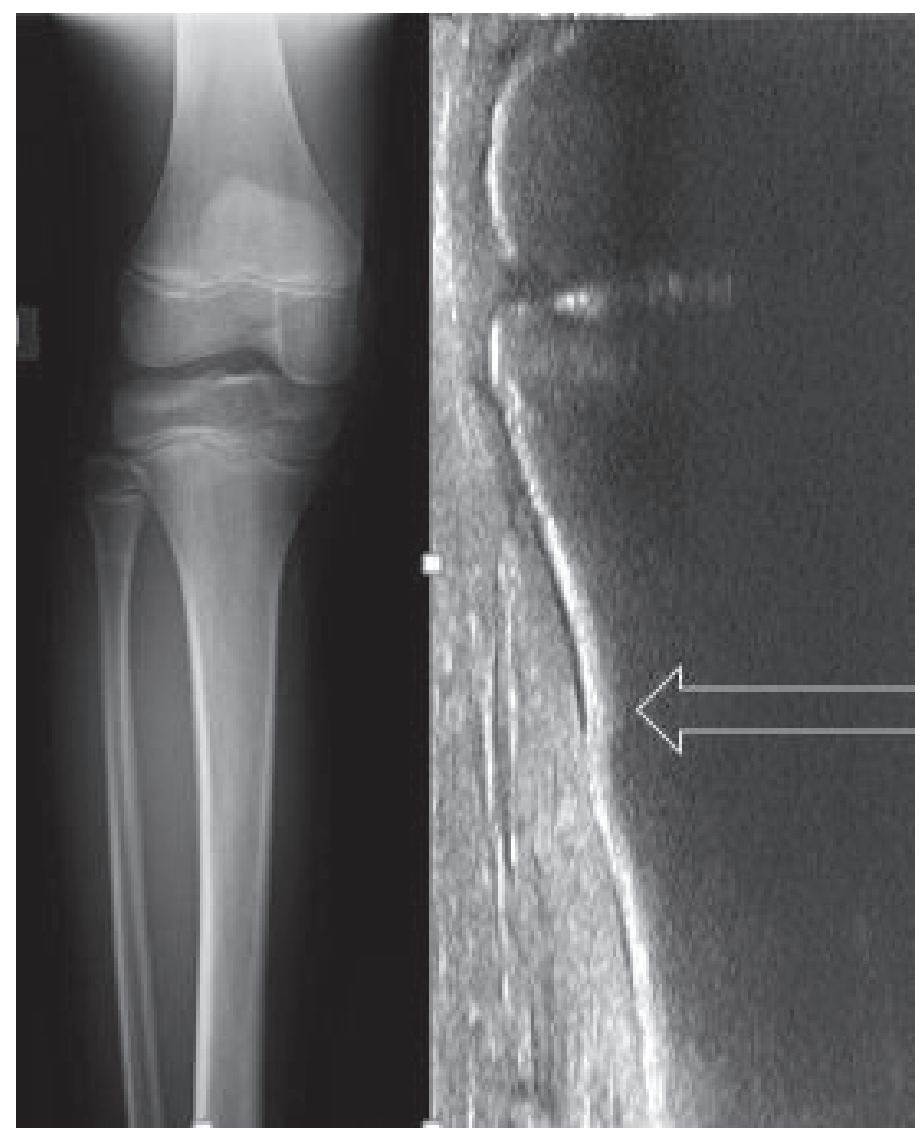

15. ábra

Élsportoló gyermek lateralis térdfájdalmát okozó proximalis fáradásos fibulatörés. A csont corticalison látható megvastagodás már a callusképződés jele (nyil) 


\section{MEGBESZÉLÉS}

A fentiekben több olyan régiót soroltunk fel, ahol a gyermekkori ultrahangos törésdiagnosztika relatíve egyszerűen és sürgősségi ellátásban alapszintű képesítéssel is alkalmazható lenne. $\mathrm{Az}$ irodalomban számos beszámolót találunk egyéb csonttörések sikeres diagnosztikájáról is - ezek azonban vagy magasabb szintű szonográfiás képzettséget igényelnek, vagy jóval alacsonyabb szenzitivitású, specificitású egyedi esetek - semmiképpen nem a rutin részei (42). Az akut gyermektraumatológiai ellátás során ugyanakkor minimum az esetek 70-80\%-ában a fenti régiók valamelyike sérül, így az ultrahangnak különösen nagy szerepe lehetne az ellátás gyorsításában, a differenciáldiagnosztikában, illetve a fölösleges röntgenvizsgálatok redukciójában (42).

Bár az ultrahang törésdiagnosztikai hatékonysága évtizedek óta ismert, a mai napig nem állnak rendelkezésünkre magas szintű evidenciák, amelyek a fentiekben részletezett alkalmazási lehetőségeket tudományosan alátámasztanák. Az irodalomban fellelhető számos közlemény jelentős része sürgősségi osztályok vagy egy-egy centrum által végzett relatív kisebb esetszámok alapján vonta le következtetéseit (42).

$\mathrm{Az}$ Európai Musculoskeletalis Radiológiai Társaság (European Society of Musculoskeletal Radiology - ESSR) 2017-ben kiadott egy közleményt, amely a mozgásszervi ultrahangvizsgálatok egyes kórképekre vonatkozó jelenlegi evidenciáit is tartalmazza. A konszenzus szerint több régió törése (könyök, térd, proximalis humerus, tibia) is vizsgálható ultrahanggal, de a jelenlegi információk birtokában ez többnyire egyéb képalkotó lehetőségek hiányában ajánlott, és az ultrahangos törésdiagnosztika hatékonyságáról egyáltalán nem állnak rendelkezésre A-típusú bizonyítékok (43).

$A z$ Európai Orvosi és Biológiai Ultrahang Társaságok Szövetsége (EFSUMB) 2016-ban kiadott egy kifejezetten gyermekkorra vonatkoztatott ajánlást, amely egyaránt tartalmazza a módszertani, dokumentációs, személyi és tárgyi feltételeit a legbiztonságosabban alkalmazható gyermekkori proximalis és distalis humerus, valamint distalis alkari törések szonográfiás diagnosztikájának, de a módszer egyelőre nem elfogadott rutineljárás része sehol a világon (1).

Eddig egy hazai közlemény jelent meg a témában, amely distalis alkartörések ultrahangos vizsgálata során két centrum, összesen 437 esetszámát elemezve, a nemzetközi irodalomban fellelhetőekhez hasonlóan kedvező eredményre jutott (48).

$\mathrm{Az}$ Országos Traumatológiai Intézetben 2011 óta foglalkozunk gyermekkori szonográfiás törésdiagnosztikával, az utóbbi években több gyermektraumatológiai centrum (Budapest, Heim Pál Kórház, Pécs, Szeged) is elkezdte alkalmazását. A módszer hazai protokolljának és jogi hátterének megteremtése még várat magára.

$\mathrm{Az}$ egyes anatómiai régiók további nagy esetszámú, prospektív és multicentrikus vizsgálatán és a tárgyi feltételek megteremtésén túl a rutin ultrahangos törésdiagnosztika további feltétele az alapszintű musculoskeletalis ultrahangos oktatás ortopéd-traumatológiai szakképzésbe való iktatása is. A szerzők hangsúlyozzák, hogy az ultrahangos törésdiagnosztika célja nem a röntgenfelvételek mellőzése, hanem egy, a hagyományos rutin radiológiai eljárásokat kiegészítő, azt ésszerüen redukáló, ellátást gyorsító, esetenként további információkat adó költséghatékony metódus megteremtése. 


\section{IRODALOM}

1. Ackermann I., Eckert K.: Bone fracture ultrasound. EFSUMB Course Book. 07. 07. 2015. 12: 48.

2. Ackermann O., Liedgens P., Eckert K., Chelangattucherry E., Ruelander C., Emmanouilidis I., Ruchholtz S.: Ultrasound diagnosis of juvenile forearm fractures. J. Med. Ultrason. (2001). 2010. 37. (3): 123-127.

3. Acuna J., Situ-LaCasse E., Jamplis R. P., Amini R., Adhikari S.: Point-of-care ultrasound evaluation of tibial avulsion fractures. Cureus, 2018. 10. (5): e2677 https://doi.org/10.7759/cureus.2677

4. Aksay E., Kilic T. Y., Yesılaras M., Tur F. C., Sever M., Kalenderer O.: Accuracy of bedside ultrasonography for the diagnosis of finger fractures. Am. J. Emerg. Med. 2016. 34. (5): 809-812. https://doi.org/10.1016/i.ajem.2016.01.010

5. Alexander J. E., Seibert J. J., Glasier C. M., Williamson S. L., Aronson J., McCarthy R. E., Rodgers A. B., Corbitt S. L.: High-resolution hip ultrasound in the limping child. J. Clin. Ultrasound, 1989. 17. (1): 19-24. https://doi.org/10.1002/icu.1870170105

6. Aponte E. M., Novik J. I.: Identification of lipohemarthrosis with point-of-care emergency ultrasonography: case report and brief literature review. J. Emerg. Med. 2013. 44. (2): 453-456. https://doi.org/10.1016/i.jemermed.2012.07.062

7. Barata I, Spencer R, Suppiah A, Raio C, Ward MF, Sama A.: Emergency ultrasound in the detection of pediatric long-bone fractures. Pediatr. Emerg. Care, 2012. 28. (11): 1154-1157. https://doi.org/10.1097/PEC.0b013e3182716fb7

8. Blankstein A.: Ultrasound in the diagnosis of clinical orthopedics: The orthopedic stethoscope World J. Orthop. 2011. 2. (2): 13-24. https://doi.org/10.5312/wjo.v2.i2.13

9. Bonasso P. C., Dassinger M. S., Wyrick D. L., Gurien L. A., Burford J. M., Smith S. D.: Review of bedside surgeon-performed ultrasound in pediatric patients J. Pediatr. Surg. 2018. 53. (11): 2279-2289. https://doi.org/10.1016/i.jpedsurg.2018.04.040

10. Bozorgia F., Azarb M. S., Montazera S. H., Heidaria S. F., Khalilianc A.: Accuracy of ultrasound for diagnosis of femur bone fractures in traumatic patients. J. Clin. Exp. Orthop. 2017. 3: 27.

11. Chartier L. B., Bosco L., Lapointe-Shaw L., Chenkin J.: Use of point-of-care ultrasound in long bone fractures: a systematic review and meta-analysis. CJEM, 2017. 19. (2): 131-142. https://doi.org/10.1017/cem.2016.397

12. Chen K. C., Lin A. C., Chong C. F., Wang T. L.: An overview of point-of-care ultrasound for soft tissue and musculoskeletal applications in the emergency department. J. Intensive Care, 2016. 4: 55. https://doi.org/10.1186/540560-016-0173-0

13. Choi J. Y., Lim Y. S., Jang J. H., Park W. B., Hyun S. Y., Cho J. S.: Accuracy of bedside ultrasound for the diagnosis of skull fractures in children aged 0 to 4 years. Pediatr. Emerg. Care, 2018. Apr 24. [Epub ahead of print] https://doi.org/10.1097/PEC.0000000000001485

14. Cook P. C.: Transient synovitis, septic hip, and Legg-Calvé-Perthes disease: an approach to the correct diagnosis. Pediatr. Clin. North Am. 2014. 61. (6): 1109-1118. https://doi.org/10.1016/i.pcl.2014.08.002

15. Cross K. P., Warkentine F. H., Kim I. K., Gracely E., Paul R. I.: Bedside ultrasound diagnosis of clavicle fractures in the pediatric emergency department. Acad. Emerg. Med. 2010. 17. (7): 687-693. https://doi.org/10.1111/i.1553-2712.2010.00788.x

16. Eckert K., Ackermann O., Schweiger B., Radeloff E., Liedgens P.: Sonographic diagnosis of metaphyseal forearm fractures in children: a safe and applicable alternative to standard x-rays Pediatr. Emerg. Care, 2012. 28. (9): $851-854$. https://doi.org/10.1097/PEC.0b013e318267a73d

17. Eckert K., Ackermann O., Schweiger B., Radeloff E., Liedgens P.: Ultrasound evaluation of elbow fractures in children. J. Med. Ultrason. (2001). 2013. 40. (4): 443-451.

18. Eckert K., Ackermann O.: Sonographische Frakturdiagnostik. Radiologe, 2015. 55. (11): 992-924, 996-999.

19. Ekinci S., Polat O., Günalp M., Demirkan A., Koca A.: The accuracy of ultrasound evaluation in foot and ankle trauma. Am. J. Emerg. Med. 2013. 31. (11): 1551-1555. https://doi.org/10.1016/i.ajem.2013.06.008

20. Farbaky Zs.: A mozgásszervi ultrahangvizsgálat alapjai. 4. kiad. Bp. Tordas K. 2017.

21. Fukushima Y., Ray J., Kraus E., Syrop I. P., Fredericson M. A.: A review and proposed rationale for the use of ultrasonography as a diagnostic modality in the identification of bone stress injuries. J. Ultrasound Med. 2018. 37. (10): $2297-2307$. https://doi.org/10.1002/jum.14588

22. Gleeson T., Blehar D.: Point-of-care ultrasound in trauma. Semin. Ultrasound CT MR, 2018. 39. (4): $374-383$. https://doi.org/10.1053/i.sult.2018.03.007

23. Hoffman D. F., Adams E., Bianchi S.: Ultrasonography of fractures in sports medicine. Br. J. Sports Med. 2015. 49. (3): 152160. https://doi.org/10.1136/bjsports-2014-094217

24. Hübner U., Schlicht W., Outzen S., Barthel M., Halsband H.: Ultrasound in the diagnosis of fractures in children. J. Bone Joint Surg. Br. 2000. 82-B. (8): 1170-1173. https://doi.org/10.1302/0301-620X.82B8.0821170

25. Joshi N., Lira A., Mehta A., Paladino L., Sinert R.: Diagnostic accuracy of history, physical examination, and bedside ultrasound for diagnosis of extremity fractures in the emergency department: A systematic review. Acad. Emerg. Med. 2013. 20. (1): 1-15. https://doi.org/10.1111/acem.12058

26. Kachewar S. G., Kulkarni D. S.: Utility of diagnostic ultrasound in evaluating fracture healing. J. Clin. Diagn. Res. 2014.8. (3): 179-180. https://doi.org/10.7860/JCDR/2014/4474.4159

27. Katzer C., Wasem J., Eckert K., Ackermann O., Buchberger B.: Ultrasound in the diagnostics of metaphyseal forearm fractures in children: A systematic review and cost calculation. Pediatr. Emerg. Care, 2016. 32. (6): $401-407$. https://doi.org/10.1097/PEC.0000000000000446

28. Kilic T. Y., Yesilaras M., Atilla O. D., Turgut A.: The accuracy of point-of-care ultrasound as a diagnostic tool for patella fractures. Am. J. Emerg. Med. 2016. 34. (8): 1576-1578. https://doi.org/10.1016/i.ajem.2016.05.073 
29. Klos B., Scholtes M., Konijnenberg S: High prevalence of all complex Segond avulsion using ultrasound imaging. Knee Surg. Sports Traumatol. Arthrosc. 2017. 25. (4): 1331-1338. https://doi.org/10.1007/s00167-017-4532-8

30. Kozaci N., Ay M. O., Avci M., Beydilli I., Turhan S., Donertas E., Ararat E.: The comparison of radiography and pointof-care ultrasonography in the diagnosis and management of metatarsal fractures. Injury, 2017. 48. (2): $542-547$. https://doi.org/10.1016/i.injury.2016.12.018

31. Leitgeb N., Bodenteich A., Schweighofer F, Fellinger M.: Sonographische Frakturdiagnostik. Ultraschall. Med. 1990. 11. (4): 206-209. https://doi.org/10.1055/s-2007-1011563

32. Lewis D., Logan P.: Sonographic diagnosis of toddler's fracture in the emergency department. J. Clin. Ultrasound, 2006. 34. (4): 190-194. https://doi.org/10.1002/jcu.20192

33. Maeda M., Maeda N., Takaoka T., Tanaka Y.: Sonographic findings of chondral avulsion fractures of the lateral ankle ligaments in children. J. Ultrasound Med. 2017. 36. (2): 421-432. https://doi.org/10.7863/ultra.15.09008

34. Nimkin K., Kleinman P. K., Teeger S., Spevak M. R.: Distal humeral physeal injuries in child abuse: MR imaging and ultrasonography findings. Pediatr. Radiol. 1995. 25. (7): 562-565. https://doi.org/10.1007/BF02015796

35. Palaniappan M., Indiran V., Maduraimuthu P.: Ultrasonographic diagnosis of slipped capital femoral epiphysis. Pol. J. Radiol. 2017. 82. 149-151. https://doi.org/10.12659/PJR.900504

36. Parri N., Crosby B. J., Glass C., Mannelli F., Sforzi I., Schiavone R., Ban K. M.: Ability of emergency ultrasonography to detect pediatric skull fractures: a prospective, observational study. Emerg. Med. 2013. 44. (1): 135-141.

37. Patel R. M., Tollefson B. J.: Bedside ultrasound detection of long bone fractures. J. Miss. State Med. Assoc. 2013. 54. (6): 159-162.

38. Pearce T., Cobby M.: Radiographically occult fracture of the tibial epiphysis: sonographic findings with CT correlation. J. Clin. Ultrasound, 2011. 39. (7): 425-426. https://doi.org/10.1002/icu.20814

39. Ramirez-Schrempp D., Vinci R. J., Liteplo A. S.: Bedside ultrasound in the diagnosis of skull fractures in the pediatric emergency department. Pediatr. Emerg. Care, 2011. 27. (4): 312-314. https://doi.org/10.1097/PEC.0b013e3182131579

40. Sabour S.: Bedside ultrasonography as a diagnostic tool for the fifth metatarsal fractures: methodological concern in reliability analysis. Am. J. Emerg. Med. 2014. 32. (5): 470. https://doi.org/10.1016/i.ajem.2014.01.012

41. Saul T., Ng L., Lewiss R. E.: Point-of-care ultrasound in the diagnosis of upper extremity fracture-dislocation. A pictorial essay. Med. Ultrason. 2013. 15. (3): 230-236. https://doi.org/10.11152/mu.2013.2066.153.ts1/n2

42. Schmid G. L., Lippmann S., Unverzagt S., Hofmann C., Deutsch T., Frese T.: The investigation of suspected fracture - a comparison of ultrasound with conventional imaging. Systematic review and meta-analysis. Dtsch. Arztebl. Int. 2017.114. (45): 757-764.

43. Sconfienza L. M., Albano D., Allen G., Bazzocchi A., Bignotti B., Chianca V., Facal de Castro F., Drakonaki E. E., Gallardo E., Gielen J., Klauser A. S., Martinoli C., Mauri G., McNally E., Messina C., Mirón Mombiela R., Orlandi D., Plagou A., Posadzy M., de la Puente R., Reijnierse M., Rossi F., Rutkauskas S., Snoj Z., Vucetic J., Wilson D., Tagliafico A. S.: Clinical indications for musculoskeletal ultrasound updated in 2017 by European Society of Musculoskeletal Radiology (ESSR) consensus. Eur. Radiol. 2018. Jun 6. [Epub ahead of print] https://doi.org/10.1007/s00330-018-5474-3

44. Simanovsky N., Lamdan R., Hiller N.: Sonographic detection of radiographically occult fractures in pediatric ankle and wrist injuries. J. Pediatr. Orthop. 2009. 29. (2): 142-145. https://doi.org/10.1097/BPO.0b013e318198452e

45. Tokarski J., Avner J. R., Rabiner J. E.: Reduction of radiography with point-of-care elbow ultrasonography for elbow trauma in children. J. Pediatr. 2018. 198: 214-219.e2 https://doi.org/10.1016/i.jpeds.2018.02.072

46. Tuijthof G. J., Kok A. C., Terra M. P., Aaftink J. F., Streekstra G. J., van Dijk C. N., Kerkhoffs G. M.: Sensitivity and specificity of ultrasound in detecting (osteo)chondral defects: a cadaveric study. Ultrasound Med. Biol. 2013. 39. (8): 1368-1375. https://doi.org/10.1016/j.ultrasmedbio.2013.02.011

47. Tuzun H. Y., Turkkan S., Arsenishvili A., Bahtiyar E. E.: Accuracy of bedside ultrasonography for the diagnosis of phalanx fractures. Am. J. Emerg. Med. 2016. 34. (8): 1698. https://doi.org/10.1016/i.ajem.2016.05.029

48. Varga M., Gáti N., Kalóz E., Bíró Zs., Szeverényi Cs., Kardos D., Józsa G.: Ultrasonographic diagnosis of distal pediatric forearm fractures. Orv. Hetil. 2017. 158. (24): 944-948. https://doi.org/10.1556/650.2017.30763

49. Warkentine F. H., Horowitz R., Pierce M. C.: The use of ultrasound to detect occult or unsuspected fractures in child abuse. Pediatr. Emerg. Care, 2014. 30. (1): 43-46. https://doi.org/10.1097/PEC.0000000000000064

50. Wawrzyk M., Sokal J., Andrzejewska E., Przewratil P.: The role of ultrasound imaging of callus formation in the treatment of long bone fractures in children. Pol. J. Radiol. 2015. 80. 473-478. https://doi.org/10.12659/PJR.894548

51. Wellsh B. M., Kuzma J. M.: Ultrasound-guided pediatric forearm fracture reductions in a resource-limited ED. Am. J. Emerg. Med. 2016. 34. (1): 40-44. https://doi.org/10.1016/i.ajem.2015.09.013

\section{Dr. Varga Marcell}

Országos Traumatológiai Intézet

1081 Budapest, Fiumei út 17. 